\title{
New teeth of nodosaurid ankylosaur from the Lower Cretaceous of Southern England
}

William T. Blows and Kerri Honeysett

Acta Palaeontologica Polonica 59 (4), 2014: 835-841 doi: http://dx.doi.org/10.4202/app.2012.0131

We present new nodosaurid teeth from the Valanginian of Bexhill, Sussex and the Barremian of the Isle of Wight, the first from the Lower Cretaceous of the United Kingdom. Teeth found during the mid-1800s from the Valanginian and ascribed to the nodosaurid Hylaeosaurus are probably from sauropod dinosaurs. The Isle of Wight tooth could possibly be referred to Polacanthus foxii, the teeth of which are unknown. These new English nodosaurid teeth are similar to those of North American and European Jurassic to Late Cretaceous nodosaurids, especially the American Gastonia, Texasetes, Mymoorapelta, Gargoyleosaurus, and the European Hungarosaurus.

Key words: Dinosauria, Nodosauridae, Polacanthus, ankylosaur, Valanginian, Barremian, Cretaceous, England.

William T. Blows [w.t.blows@ city.ac.uk] Department of Applied Biological Sciences, City University, London, EC1A 7QN, England;

Kerri Honeysett [kerrihoneysett@googlemail.com], 10 Camperdown Street, Bexhill on Sea, East Sussex, TN39 5BE, England.

This is an open-access article distributed under the terms of the Creative Commons Attribution License (for details please see creativecommons.org), which permits unrestricted use, distribution, and reproduction in any medium, provided the original author and source are credited. 
